\title{
Journalism and media education in Nepal: A critical overview
}

\author{
- Laxman Datt Pant
}

\section{Introduction}

This article explores the relevance of journalism education in Nepal based on personal observations of university teachinglearning practices. In particular, I focus on the triangular relationship between corporate, educational socioeconomic challenges of ournalism/media education. I also analyze the recent trend of journalism and mass communication education in Nepal shedding light on the challenges of Nepalese media education system especially in the university level. I further suggest how media educators help determine what news is (not), and at the same time describe avenues for engaging media educators, policy makers and content producers for meeting the market demands.

\section{Nepali media education scenario}

There are different nomenclatures used for the journalism and mass communication degrees and a number of terms are used synonymously. The terminologies like Journalism, Mass Communication and Media Studies are very common when referring to the degree emphasis by universities in Nepal. The course is also offered at secondary and higher secondary levels in different schools and +2 colleges across the country. A number of training institutes are also offering short term trainings for aspiring journalists. There are at least two hundred +2 colleges, 40 undergraduate colleges and three universities offering courses in mass communication and journalism. A course on Journalism has also been started at the school level. However, the courses offered at different levels lack uniformity resulting in poor performance in the field.

Bodhi, 3 (1), 21-34. ISSN 2091-0479. (C) 2009 Kathmandu University 


\begin{tabular}{|l|l|l|l|l|}
\hline SN & Insti/Univ & Levels & Courses & Remarks \\
\hline 1. & TU & $\begin{array}{l}\text { Masters, } \\
\text { Bachelors and } \\
\text { Intermediate } \\
\text { Levels }\end{array}$ & $\begin{array}{l}\text { MA-JMC } \\
\text { BA-JMC } \\
\text { IA-JMC }\end{array}$ & $\begin{array}{l}\text { Specialization } \\
\text { Optional }\end{array}$ \\
\hline 2. & Purb.U & $\begin{array}{l}\text { Masters and } \\
\text { Bachelors }\end{array}$ & $\begin{array}{l}\text { MA-MCJ } \\
\text { BA-MCJ/ } \\
\text { BMT }\end{array}$ & Specialization \\
\hline 3. & KU & Bachelors & BMS & Specialization \\
\hline 4. & HSEB & Intermediate & MCJ $(+2)$ & Optional \\
\hline 5. & $\begin{array}{l}\text { GoN } \\
\text { Board }\end{array}$ & SLC & $\begin{array}{l}\text { Journalis } \\
\text { m- Part 1 } \\
\text { and 2 }\end{array}$ & Optional \\
\hline
\end{tabular}

Table 1: Journalism and Mass Communication courses at different levels in Nepal

A number of media houses also train some of their own journalists by selecting potential students with necessary skills and putting them through journalism training workshops and on-the-job training intern programs. Such media houses believe that giving such opportunity builds employee loyalty and increases long-term employee retention rates while also proving cost-efficient. Media Organizations like Nepal Television, Radio Nepal, Kantipur Publications, Avenues Television and others also run on-the-job training programs for aspiring journalists.

In the last one decade, journalism and mass communication education has witnessed a lot of demand from students' intent on pursuing careers in journalism and mass communications. The increase in private television channels, FM radio stations, newspapers, news portals and blogs has been a major cause behind attraction to journalism and mass communication education.

\section{Relevance of journalism education in Nepal}

After being neglected for a long time, journalism and mass communication courses are witnessing considerable demand

Bodhi, 3 (1), 21-34. ISSN 2091-0479. (C) 2009 Kathmandu University 
from students' intent on pursuing careers in journalism and communication. While the boom in private television channels and FM radio stations fuels this demand, it is not uniform across all institutions, and the reasons vary. What used to be a postgraduate degree specialization is now also being offered in many institutions as an undergraduate specialization. In addition, there are other questions about the level of courses and how they tie into each other, the kinds and consistency of training offered, the course curriculum and duration and the overall quality of the education.

Media education, development and national policy should be linked to thresh out policies on media education. To this end, the universities and policy-makers should give priority to media education to cater to the growing demand of qualified hands in the media sector that has arrived at an important stage of its development after the restoration of democracy (L. D. Rai, personal communication, 2008, June 23).

Journalism, after all, has to help us cope with the info-glut. As a close society, however, general Nepalese people do not put a lot of trust in journalism, ranking journalists just below the "rich people" and just above "government officials". Indeed our ambivalence about journalists is comparable to our ambivalence about teachers and librarians. While many people pay lip service to the need for a free press, public education and libraries -- saying they are essential sources of information and knowledge and, thus, essential to the security and health of our democracy -- most journalists in Nepal rarely pay any attention to the needs of these idealized professions.

According to Pant (2008), "Media educators in Nepal should produce journalists who can make decisions about what modern Nepal reads and watches. Today, it is obvious that journalism is straining under increasing corporate, educational and socioeconomic pressures" (p. 4). With reference to the general confusion underlying Tribhuvan University system, Pokharel

Bodhi, 3 (1), 21-34. ISSN 2091-0479. (C) 2009 Kathmandu University 
(2001) expresses concerns about the growing need of policy formulation and implementation in journalism education:

Journalism education as a discipline of study appears to be heading into confusion in the absence of clear national policy and resource allocation plans. This is the only development sector that is deprived of state funds and, subsequently, is obliged to look for external resources and support. There are no specific criteria adopted for the selection of teachers in journalism. The criteria developed by the Universities for other subjects have not been applied in this case for several reasons. For the moment, the problem is not serious as the faculty is limited to one campus in Kathmandu which has, somehow managed to assemble a bevy of staff of matchable standard. The issue needs to be resolved for the sake of uniformity and adoption by other campus also. (p. 2)

\section{Major concerns in journalism education}

There is tremendous ambiguity in terms of what constitutes a formal degree in journalism. The range of degrees offered at three universities-Tribhuwan University, Kathmandu University and Purbanchal University differs from 'pure theoretical analyses at one end of the spectrum to 'completely hands-on skills training' at the other end of the spectrum.

These degrees are advertised as preparing the students for careers in print, radio, television, advertising, cinema, NGO's/INGO's or new media or some form of combination of more than one. Nevertheless, there is no formal government document or specific professional oversight body to structure or regulate these courses. This issue was also raised in my interviews with some experts. They recognized that there is a phenomenal demand for journalism courses in Nepal today. They also feel that there is no clear direction or consistency in

Bodhi, 3 (1), 21-34. ISSN 2091-0479. (C) 2009 Kathmandu University 
the various journalism courses offered around the country. (Pant, 2008, p. 4)

Journalism education is undergoing dramatic changes with the increasing demand for workforce in the booming business of television channels, newspapers, content writing and corporate communicators.

Concerning the specialization crisis in journalism curricula of Nepal L.D. Rai says,

Universities offering mass communication and journalism course at undergraduate and postgraduate levels lack adequate infrastructures. The courses are designed in such a way that the students are introduced to the course and the skills at the postgraduate (PG) level, however, with no specializations, exposing them to all media. The universities should know how to go with society and the course should be updated accordingly. The entry point for those wish to study journalism should be made strict. (Personal communication, 2009, June 23)

The academia are not keeping in pace with the fast changing media scenario in the country. The universities have not changed or updated their syllabi for years. Whatever changes have been made, are very cosmetic. It's unfortunate that with the explosion of electronic media, there is no university which offers a very comprehensive course in broadcast.

Humanities and social sciences are usually neglected in most universities as far as fund allocation is concerned. Educational administrators generally find it difficult to understand that their journalism departments ought to be treated in the same way as their engineering schools--pumped in with resources, both financial and academic, and with quality assurance mechanisms befitting a professional course.

Bodhi, 3 (1), 21-34. ISSN 2091-0479. (C) 2009 Kathmandu University 
There is no clear direction or consistency in the various journalism courses offered at schools and universities. One of the major problems in journalism education today is a total mismatch between the industry practices and what is taught in journalism schools and universities. Most of the teachers of Journalism have degrees in other than journalism disciplines and a majority of them have no experience in media whatsoever. Furthermore, there is also a complete lack of guidelines in the proportion of skills versus theoretical content in the course curriculum (N. M. Adhikary, personal communication, 2009, June 5).

Highlighting the importance of incorporating theory and practice N. M. Adhikary points out,

A healthy balance between theoretical components with the professional skills - which is sadly lacking in the present system - needs to be introduced. The academic institutions - specially the universities have a journalism syllabus, which is heavily loaded with theoretical components. Much of it is outdated. (ibid.)

Universities are important for entry-level journalism training. International media developers should consider investing in journalism schools; however, the type and level of assistance should depend on local circumstances. International funders are showing interest in mapping journalism education worldwide. Such efforts must draw information from every part of the world in order to help media developers find the most promising entities for investment of their limited development funds.

Some traditional journalism curricula do not leave room for interdisciplinary studies now sought in certain job markets. It is stated that, in some locales, those who leave journalism school knowing only "the skill of communication" do not find journalism jobs as readily as those trained in politics, philosophy, or law (Ferguson, 2004, p. 141). Strategies

Bodhi, 3 (1), 21-34. ISSN 2091-0479. (C) 2009 Kathmandu University 
addressing this issue include visiting fellowships, team-teaching across disciplines, and joint-degree programs with other university departments. Partnership models between universities and professional media can also address this issue. In some cases, universities provide the interdisciplinary studies, while the media organizations provide journalism training; in others, journalism organizations, notably the British Broadcasting Corporation (BBC), set up their own colleges of journalism.

Curriculum considerations include the hallmarks of an ideal journalism curriculum. The three axes of study include tradecraft, the role of journalism in society, and non-journalism courses that expand the student's knowledge of the world (Franklin, Hamer, Hanna, Kinsey and Richardson, 2005, p. 272). Non-university training is also filling an untapped niche, as stated here, through non-degree courses, workshops, and online training. "Catch-up" pedagogy needs to include new media technologies and adapt some of its interactivity and peerto-peer features, according to the report. Faculty as facilitators of learning, who stress independent student work, with students negotiating their own assignments and submitting to peer assessment could serve students as a model for the online journalist who guides the reader interactively through the news. (UNESCO, 2007, p. 24).

\section{Recent challenges}

\section{Lack of regulation and supervision}

There is vagueness in terms of what constitutes a formal degree in journalism, mass communication and media studies in Nepal. These degrees are advertised as preparing the students for careers in print, radio, television, and new media. However, there is no specific professional oversight body to structure or regulate these courses.

Bodhi, 3 (1), 21-34. ISSN 2091-0479. (C) 2009 Kathmandu University 
There is no clear direction in the various journalism courses offered by the universities. The quality of journalism education is not out of the debate. As Basnet points out:

Journalism education in Nepal is undergoing dramatic changes with the increasing demand for manpower in the media. What is - even a decade ago - a neglected choice in Nepal, journalism and mass communication has now become a much sought-after profession of the generation. Journalism colleges seem to be the new growth area in private educational institutions. However, proliferation in journalism courses has more to do with cashing in on the demand at the expense of offering good education to students. (S. S. Basnet, personal communication, 2009, June 23)

\section{Lack of human resources and infrastructure}

Lack of resources and physical infrastructure is a major concern for journalism teachers and students in Nepal. This includes lack of proper infrastructures, labs related to broadcast and photography or sound technologies, lack of relevant learning materials and books. The lack of competent faculty members is another burning problem the colleges and universities are facing.

Notable in this regard is the case of television infrastructures. Almost all bachelor's and master's level colleges are offering television courses in some parts, years or semesters. But the colleges are facing infrastructure problems. Most of them do not have production facilities. For example, the central department of journalism and mass communication of TU -oldest of its type to offer journalism education -- lacks production-related infrastructures including computers, sound and video labs. Private colleges affiliated to Tribhuvan and Purbanchal are in similar condition. Kathmandu University, which offers a comparatively new course, Bachelor in Media Studies (BMS), is yet to develop sufficient resources.

Bodhi, 3 (1), 21-34. ISSN 2091-0479. (C) 2009 Kathmandu University 
In fact, there is a vast gap between philosophical and practical knowledge envisioned at different levels of education. The gap becomes even wider when classes are run without adequate administrative and academic knowledge-base for courses. Colleges are found to have devised a simpler compromise creating a semblance of compensation by reducing the costs and evading potential public grumbles.

The basic problem that one can experience as a teacher of Mass Communication and Journalism is the lack of infrastructure. There is a lack of colleges that can boast of any kind of infrastructure. There have been instances, where some colleges even resort to hiring the required equipments and manpower especially in the photojournalism course. Pant (2009) says,

The quality and competency of available faculty to teach these courses is another challenge to journalism education in Nepal. The university administration and the college authorities do not check the degrees and competencies of the faculty members. (p. 4)

Here is a relevant story. One college running an undergraduate course hires a television personality to teach journalism. When he states that he has no degree in journalism, the college administration insists that it is not a requirement; rather his well-known face matters. Within few days, the teacher finds himself unable to continue his job as a teacher. He quits teaching. What does all this mean? There are different dimensions responsible for this issue - quality, competency, salaries, training, real world experience and the like. There is a shortage of qualified faculty in both theory and technical aspects of journalism and mass communication studies. In some colleges, journalism courses are generally taught by academics either without degrees or degrees in other than journalism and mass communication. The question here however is not of competence of the educators or the quality of knowledge they transfer, but of the credibility of the degree the students earn.

Bodhi, 3 (1), 21-34. ISSN 2091-0479. (C) 2009 Kathmandu University 
Most faculty members in the colleges and universities do not have any real world experience in the field of journalism practice. The other dimension to faculty shortage and competence that may trouble many is the increasing number of students passing out from master's level journalism and mass communication programs who are then hired by their own colleges and departments to teach students. This bears the risk of transferring the same cycle of inadequacies unless the new faculties initiate innovations and novelty in their works.

\section{Inconsistent course curriculum}

There is no clear direction in the various journalism and mass communication courses offered by different universities. The curriculum in most journalism institutions is outdated and not relevant to the skills required in the outside world. Basnet says,

One of the major problems in journalism education in Nepal today is a total mismatch between the industry practices and what is taught in the universities. Journalism teachers in Nepal follow the normal route of master's degree and a majority of them have no experience in media field. There is also a complete lack of guidelines in the proportion of skills versus theoretical content in the course curriculum. (Personal communication, 2009, June 23)

\section{Lack of industry collaboration}

The collaboration between academics and media industry professionals is regarded as crucial element in filling the gap between journalism philosophy and its practice. As Adhikary (2002, November 1, p. 5) says,

While universities appear to be increasingly involved in communication education they cannot in all cases provide all the practical training that professional need. Thus various specialized training centers and mass media organization also play an important role.

Bodhi, 3 (1), 21-34. ISSN 2091-0479. (C) 2009 Kathmandu University 
Especially media houses can provide specific courses of practical, technical and occupational instruction suitably adapted to the circumstances and demands of their work.

However, such collaborations have not been materialized yet. Rather, S. S. Basnet sees an environment of "distrust" between media professionals and academics. He says, "It is a problem everywhere perhaps that the academics accuse the professionals of 'not knowing enough', while the professionals say that what the academics learn or teach are not relevant" (Personal communication, 2009, June 23).

It is noticeable that the practical training part is not properly addressed by the universities and colleges while prescribing the curriculum. The academics need to inculcate professional aptitude for the course by adopting different activities with study projects, records, seminars, field visits, exhibitions, extension lectures by media professionals, and academicians. The collaborations and real world training helps students to find a place for work. The response from the Nepalese media industries for internships and training programs for journalism students has been encouraging but the performance of very few students has been recognized to be at par with the expectation of the industry. Basnet emphasizes a strong collaboration with the industry and says:

Certainly a point of compromise may be found at one level for mutual benefit. And this is important. With the growing challenges of the information technology, it is important that the media industry and the media academic bodies overcome their mutual mistrusts and draw up a guideline for a quality media education which will benefit both and be of great relief for the aspiring media students. (ibid.)

He further says,

Bodhi, 3 (1), 21-34. ISSN 2091-0479. (C) 2009 Kathmandu University 
I feel that all journalism colleges and universities in Nepal should have a tie-up with Newspapers, radio stations, television channels, media companies, advertisement industries and organizations so that the students get a hands-on experience on what they learn within the classroom boundary. (ibid.)

\section{Conclusion}

Though journalism and media education in Nepal bears many prospectives there are various 'wrongs' with what we have been practicing. The present perspective of journalism education and practice in Nepal is likely to turn the news media into vehicles that further distance the community members from themselves and from each other (Pant, 2008, p. 4).

The new generation is heavily interested in getting quality yet practical and professional knowledge in the field. However, the Nepalese universities and academics have not been able to meet the expectations of the new generation. It is because of the existing system of not seeing any changes in the conventional way of teaching journalism and because of our own limitations in not recognizing the need for the different technologies and the disciplines that are coming together in the field.

Journalism educators need to be aware of current communications findings and to prepare their students, as well as in-service journalists, for new ways of professional work (McIlwaine , 2005, p. 63). The changes are urgent if journalism is to play its part in avoiding the "red shift" acceleration of science away from the grasp of societies in which it ought to be embedded as an integral and valued part (ibid).

Emphasizing the training opportunities for journalism teachers Hume (2007) says:

The media sector has changed dramatically, but many journalism programmes fail to meet the new challenges

Bodhi, 3 (1), 21-34. ISSN 2091-0479. (C) 2009 Kathmandu University 
of the industry. Media developers can help overcome this gap in several ways: funding teacher training and curriculum development, providing updated educational materials and adequate equipment, facilitating the creation of student-run media to develop practical skills, and funding cross-disciplinary partnerships and programmes. (p. 3)

In brief, provision of effective regulatory mechanisms, substantive efforts for the advancement of human resources as well as infrastructures, need-based course curricula, and collaboration of the media industry and academic plus training institutions will contribute for the development of the field. Media educators, particularly from university locations, should not hesitate to take the initiatives in this regard.

\section{References}

Adhikary, N. M. (2002, November 1). Media houses and training institutions. The Kathmandu Post, p. 5.

Franklin B., Hamer, M., Hanna, M., Kinsey, M., and Richardson, J. E. (2005). Key concepts in journalism vstudies. New Delhi: Vistaar Publications.

Hume, E. (2007). University journalism education: a global challenge. Massachusetts: University of Massachusetts.

Pant, L. D. (2008, November 21). Media education in Nepal. The Rising Nepal, p. 4.

Pant, L. D. (2009, July 22). What is wrong with media education. The Rising Nepal, p. 4.

Pokharel, G. (2001, June 6). Journalism education in Nepal: In search of new moorings. A paper presented at workshop conducted by Centre for Mass Communication Research and Studies (CMCRS, Kathmandu, Nepal.

Ferguson, R. (2004). The media in question. London: Hodder Headline Group.

Bodhi, 3 (1), 21-34. ISSN 2091-0479. (C) 2009 Kathmandu University 
United Nations Educational, Social and Cultural Organization [UNESCO]. (2007). Model curricula for journalism education for developing countries and emerging democracies. Kathmandu: Author.

Mcllwaine, S. (1991). Journalist and journalism education must grasp the democratic science opportunity. Singapore Symposium on Journalism Education (pp. 23-47). Singapore Campus, The University of Newcastle. 